medRxiv preprint doi: https://doi.org/10.1101/2020.04.24.20075333; this version posted April 28, 2020. The copyright holder for this preprint (which was not certified by peer review) is the author/funder, who has granted medRxiv a license to display the preprint in perpetuity. It is made available under a CC-BY-NC-ND 4.0 International license.

\title{
Regional differences in reported Covid-19 cases show genetic correlations with higher socio-economic status and better health, potentially confounding studies on the genetics of disease susceptibility
} Abdel Abdellaoui ${ }^{1, *}$

\author{
${ }^{1}$ Department of Psychiatry, Amsterdam UMC, University of Amsterdam, Amsterdam, the Netherlands \\ *Correspondence to: a.abdellaoui@amsterdamumc.nl
}

\section{ABSTRACT}

Background: In March 2020, England showed a rapid increase in Covid-19 cases. Susceptibility for infectious diseases like Covid-19 is likely to be partly genetic. Mapping the genetic susceptibility for Covid-19 outcomes may reveal biological mechanisms that could potentially aid in drug or vaccine developments. However, as the disease spreads unevenly across the country, regional allele frequency differences could become spuriously associated with disease prevalence.

Methods: A regional genome-wide association study (RGWAS) was conducted in 396,042 individuals from England to investigate the association between 1.2 million genetic variants and regional differences in daily reported Covid-19 cases from March $1^{\text {st }}$ to April $18^{\text {th }} 2020$.

Results: The polygenic signal increases during the first weeks of March, peaking at March $13^{\text {th }}$ with the measured genetic variants explaining $\sim 3 \%$ of the variance, including two genome-wide significant loci. The explained variance starts to drop at the end of March and reaches almost zero on April $18^{\text {th }}$. The majority of this temporary polygenic signal is due to genes associated with higher educational attainment and better health.

Conclusions: The temporary positive relationship between Covid-19 cases and regional socio-economic status (SES) at the beginning of the Covid-19 outbreak may reflect 1) a higher degree of international travelers, 2) more social contacts, and/or 3) better testing capacities in higher SES regions. These signals are in the opposite direction of expected disease risk increasing effects, which has the potential to cancel out signals of interest. Genetic association studies should be aware of the timing and location of cases as this can introduce interfering polygenic signals that reflect regional differences in genes associated with behavior. 
medRxiv preprint doi: https://doi.org/10.1101/2020.04.24.20075333; this version posted April 28, 2020. The copyright holder for this preprint (which was not certified by peer review) is the author/funder, who has granted medRxiv a license to display the preprint in perpetuity. It is made available under a CC-BY-NC-ND 4.0 International license .

\section{INTRODUCTION}

Covid-19 is the infectious disease caused by the single-stranded RNA virus severe acute respiratory syndrome coronavirus 2 (SARS-CoV-2). ${ }^{1}$ The virus was first detected in Wuhan, China, in December 2019, ${ }^{2}$ and soon thereafter spread to other parts in the world. The World Health Organization (WHO) declared a Public Health Emergency of International Concern (PHEIC) on January $30^{\text {th }}$ and a worldwide pandemic on March 11 $1^{\text {th }}$ 2020. In England, the first cases were identified in two tourists visiting York on January $29^{\text {th }}$, on January $30^{\text {th }}$ a public health information campaign was launched to advise people on how to slow the spread of the virus, the first transmission was confirmed February $28^{\text {th }}$, and a rapid increase in infections followed in the beginning of March, raising the UK risk level from moderate to high on March $12^{\text {th }} \cdot{ }^{3}$ On March $18^{\text {th }}$, schools in the UK were ordered to close, and on March $20^{\text {th }}$ restaurants, pubs, clubs, and indoor sport and leisure facilities also had to close their doors. As of April $18^{\text {th }}$, England had 95,297 reported Covid-19 cases and 15,464 reported Covid-19 related deaths.

There is much variation in the severity of Covid-19 symptoms, ranging from asymptomatic to mild flu-like symptoms to critical illness. The severity of the symptoms and the mortality rate are strongly associated with age, sex, and underlying health problems. It is not yet clear to which extent genetic susceptibility plays a role in the individual differences in Covid-19 symptoms. It is well-established however that the underlying health problems that are associated with Covid-19 symptom severity, such as obesity, diabetes, and cardiovascular disorders, are heritable complex traits that are caused by a combination of many genes with small effects and environmental influences. ${ }^{4}$ Identifying which genes are associated with Covid-19 outcomes is of great importance, as genetics are likely to play a role in individual differences in the susceptibility for infectious diseases in general, ${ }^{5}$ and drug targets with support from genetic association studies are more than twice as likely to succeed. ${ }^{6,7}$ An international effort to investigate the role of genetic susceptibility for Covid-19 is on the way, ${ }^{8}$ with UK Biobank $^{9}$ as one of the contributing cohorts. Individual-level Covid-19 test results from UK Biobank participants are still ongoing and are not part of the current study; instead, here we use the genotype data and geographic location of UK Biobank participants and link those to the total number of regional Covid-19 cases as reported by Public Health England (PHE) ${ }^{10}$. As one of the largest genotyped datasets in the world with a rich collection of phenotypic measurements $(N \sim 500,000),{ }^{9}$ UK Biobank is likely to be contributing a substantial part of the polygenic signal for Covid-19 susceptibility. It is therefore important that the possible sources of polygenic signal in datasets like these are well characterized.

UK Biobank provides a unique data resource to address questions regarding the geographic distribution of polygenic complex trait variation in ways that have not been possible before. UK Biobank allowed us recently to identify that, after controlling for ancestry, polygenic complex trait variation is not randomly distributed across geographic space in Great Britain. ${ }^{11}$ The strongest regional differences we observed were in line with regional differences in socio-economic status. ${ }^{11}$ Of the 33 complex traits and diseases we analyzed, polygenic signals associated with educational attainment showed the strongest geographic clustering after controlling for regional ancestry differences. ${ }^{11}$ People that migrated out of the poorest regions in Great Britain had the highest polygenic scores for a higher education level on average, while those that stayed had the lowest on average, a process that increased these regional genetic differences over time. ${ }^{11}$ Regional differences in health outcomes like obesity and diabetes were more in line with regional differences in genes associated with educational attainment than with genes associated with the health outcomes themselves, suggesting environmental influences that cause people from regions with lower education levels to have worse health outcomes. ${ }^{11}$ Obesity and diabetes have been associated with worse symptoms and higher fatality rates for Covid-19, ${ }^{12,13}$ raising the questions about whether we can expect regional differences in Covid-19 outcomes to show similar patterns. 
medRxiv preprint doi: https://doi.org/10.1101/2020.04.24.20075333; this version posted April 28, 2020. The copyright holder for this preprint (which was not certified by peer review) is the author/funder, who has granted medRxiv a license to display the preprint in perpetuity. It is made available under a CC-BY-NC-ND 4.0 International license .

This study investigates whether regional differences in daily reported Covid-19 cases in England during March and the first half of April 2020 are in line with regional genetic differences in UK Biobank participants. Since this study uses regional reports of Covid-19 cases instead of individual-level Covid19 outcomes, we expect to have more power to detect regional genetic correlates of social stratification if they are in line with Covid-19 outcomes and less power to detect strong polygenic signals directly related to the genetic susceptibility of Covid-19. If regional patterns of social stratification lead to associations between regional Covid-19 outcomes and genetic variants, these should be accounted for when the aim is to identify genes related to Covid-19 susceptibility in order to better understand the disease and accelerate drug target and vaccine developments.

\section{RESULTS}

\section{Data and Analysis}

Regional Genome-Wide Association Studies (RGWASs) ${ }^{11}$ were run on the cumulative number of reported Covid-19 cases for every day between March $1^{\text {st }}$ and April $18^{\text {th }} 2020$. The RGWASs were run on 396,042 UK Biobank ${ }^{9}$ participants of European descent on 1,246,531 common single-nucleotide polymorphisms (SNPs) with minor allele frequencies (MAF) > .01. In an RGWAS, all subject get assigned the same phenotype as the rest of the subjects in their region. The phenotypes were defined as 1) the regional daily cumulative number of reported Covid-19 cases, and 2) the regional daily cumulative number of reported Covid-19 cases divided by the regional adult population size according to 2018 census data (case-rate). Regional data on the number of cases were available for 151 local authority regions in England obtained from Public Health England $(\mathrm{PHE})^{10}$ and regional data on the population sizes for 149 out of the 151 regions were obtained from the Office of National Statistics (ONS) ${ }^{14}$. All RGWASs were run using the linear-mixed model approach in fastGWA. ${ }^{15}$ To control for confounding due to population stratification and family-relatedness, we corrected for a sparse genetic-relatedness matrix (GRM) and the first 100 principal components (PCs) and applied an LDSC-intercept based genomic control (GC). ${ }^{11}$ We then computed the SNP-based heritability and the genetic correlation with educational attainment (EA), based on the EA3 $\mathrm{GWAS}^{16}$ excluding all British cohorts ( $N=245,612$, SNPbased heritability $=.10$ ), using LD Score regression ${ }^{17,18}$. For more details on the methods, rationale, and interpretation of the RGWAS approach, see Abdellaoui et al $(2019)^{11}$.

\section{Longitudinal SNP-based heritability}

The upper panel in Figure 1 shows the longitudinal change in SNP-based heritability estimates from the RGWAS signals from March $1^{\text {st }}$ to April $18^{\text {th }}$. On the first day that was analyzed, there were 82 reported Covid-19 cases in England ${ }^{10}$ and a low SNP-based heritability (case-rate: $h_{2}=0.3 \%, S E=0.11$; total cases: $h_{2}=0.4 \%, S E=0.13$ ). The SNP-based heritability increased in the weeks that followed, and reached its peak on March $12^{\text {th }}$ for the total cases $\left(h_{2}=1.4 \%, S E=0.14\right)$ and on March $13^{\text {th }}$ for the caserate $\left(h_{2}=2.7 \%, \mathrm{SE}=0.18\right.$; see Figure 2$)$. The total number of reported cases in England on March $13^{\text {th }}$ was 1,959, with the highest rates in Westminster and the Royal Borough of Kensington and Chelsea (see Figure 2). While cases continued to rise, the SNP-based heritability remained relatively stable for more than a week, and began to drop after March $20^{\text {th }}$, which had 6,819 reported cases. On April $18^{\text {th }}$, the SNP-based heritability dropped down to $0.4 \%$ and $0.1 \%$ for the case-rate and the total number of cases respectively.

\section{Genetic correlations}

The bottom two panels in Figure 1 show the longitudinal change in the genetic correlation $\left(r_{\mathrm{g}}\right)$ between the RGWASs for the regional daily cumulative reported Covid-19 cases and the individual-level 
medRxiv preprint doi: https://doi.org/10.1101/2020.04.24.20075333; this version posted April 28, 2020. The copyright holder for this preprint (which was not certified by peer review) is the author/funder, who has granted medRxiv a license to display the preprint in perpetuity.

It is made available under a CC-BY-NC-ND 4.0 International license .

educational attainment GWAS (EA3) ${ }^{16}$ without British cohorts. The $r_{\mathrm{g}}$ with educational attainment showed a similar trajectory as the SNP-based heritability with respect to its significance (bottom panel of Figure 1). The point estimate of the $r_{\mathrm{g}}$ showed less variability and was .73 on March $13^{\text {th }}$. In April, it started to decrease, reaching .14 on April $18^{\text {th }}$. The standard error increased when the SNP-based heritability decreased, likely due to a weaker genetic signal. The high $r_{\mathrm{g}}$ with educational attainment is in line with the regional differences in polygenic signals associated with educational attainment that we recently observed for other regional measures of SES, health, and cultural outcomes as well. ${ }^{11}$

For the RGWAS results of March $13^{\text {th }}$, we investigated the genetic correlations with a total of 10 traits, of which 5 traits are related to socio-economic status, and 5 traits are associated with health outcomes that are considered risk factors for worse Covid-19 outcomes (Figure 2C). All genetic correlations were significant after Bonferroni correction, except for Type-2 Diabetes. The genetic correlations were all in the direction that would be expected given a positive association with higher SES $^{11}$, namely higher reported Covid-19 case-rates are in line with higher cognitive abilities, higher income, and better health outcomes (lower BMI, body fat, and cardiovascular risk, and higher selfrated health).
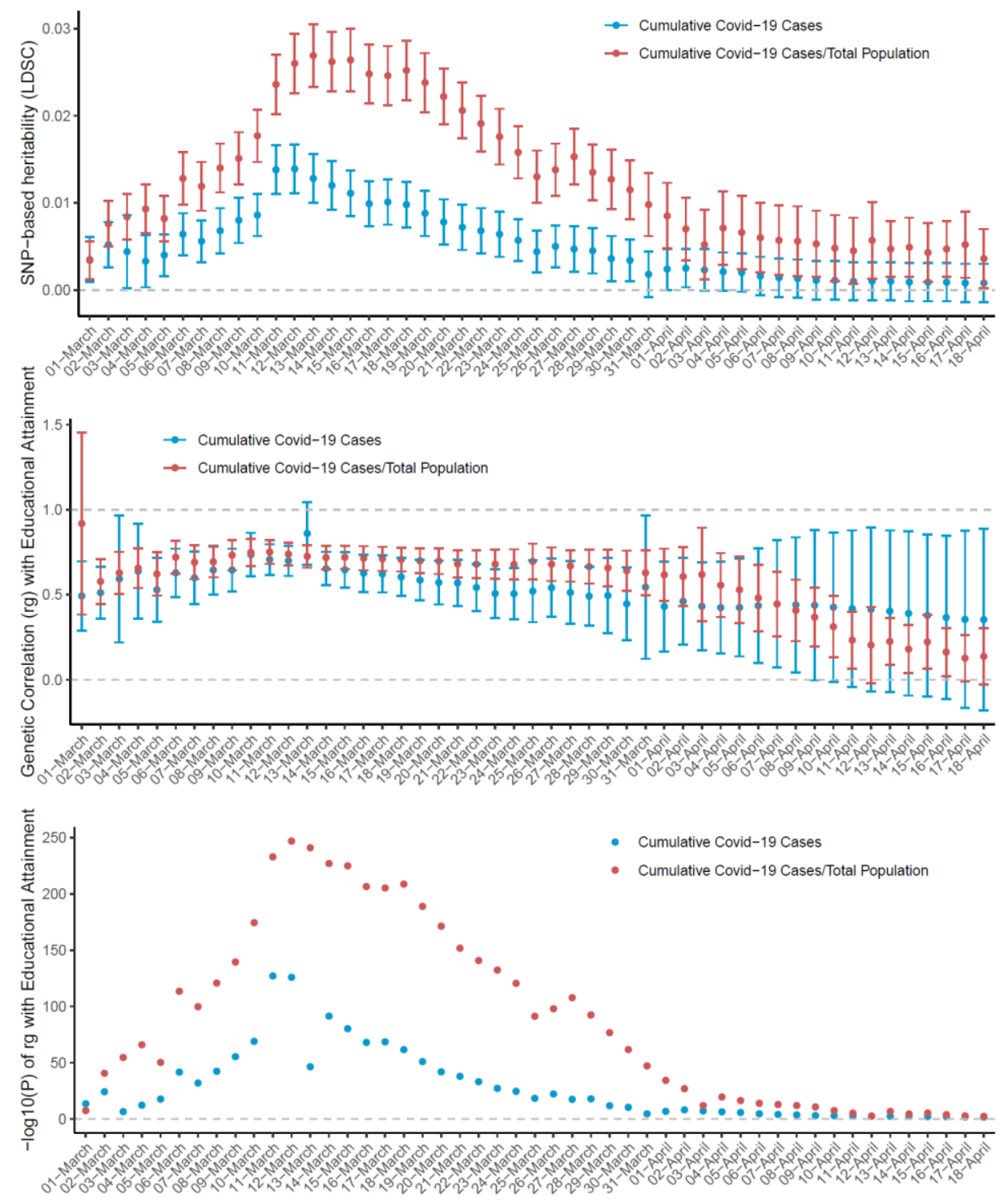

Figure 1: SNP-based heritability of the RGWAS of the daily regional cumulative reported Covid-19 cases and their genetic

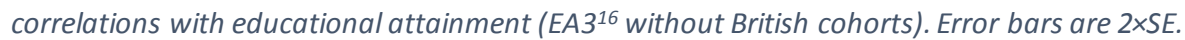


medRxiv preprint doi: https://doi.org/10.1101/2020.04.24.20075333; this version posted April 28, 2020. The copyright holder for this preprint (which was not certified by peer review) is the author/funder, who has granted medRxiv a license to display the preprint in perpetuity.

It is made available under a CC-BY-NC-ND 4.0 International license.
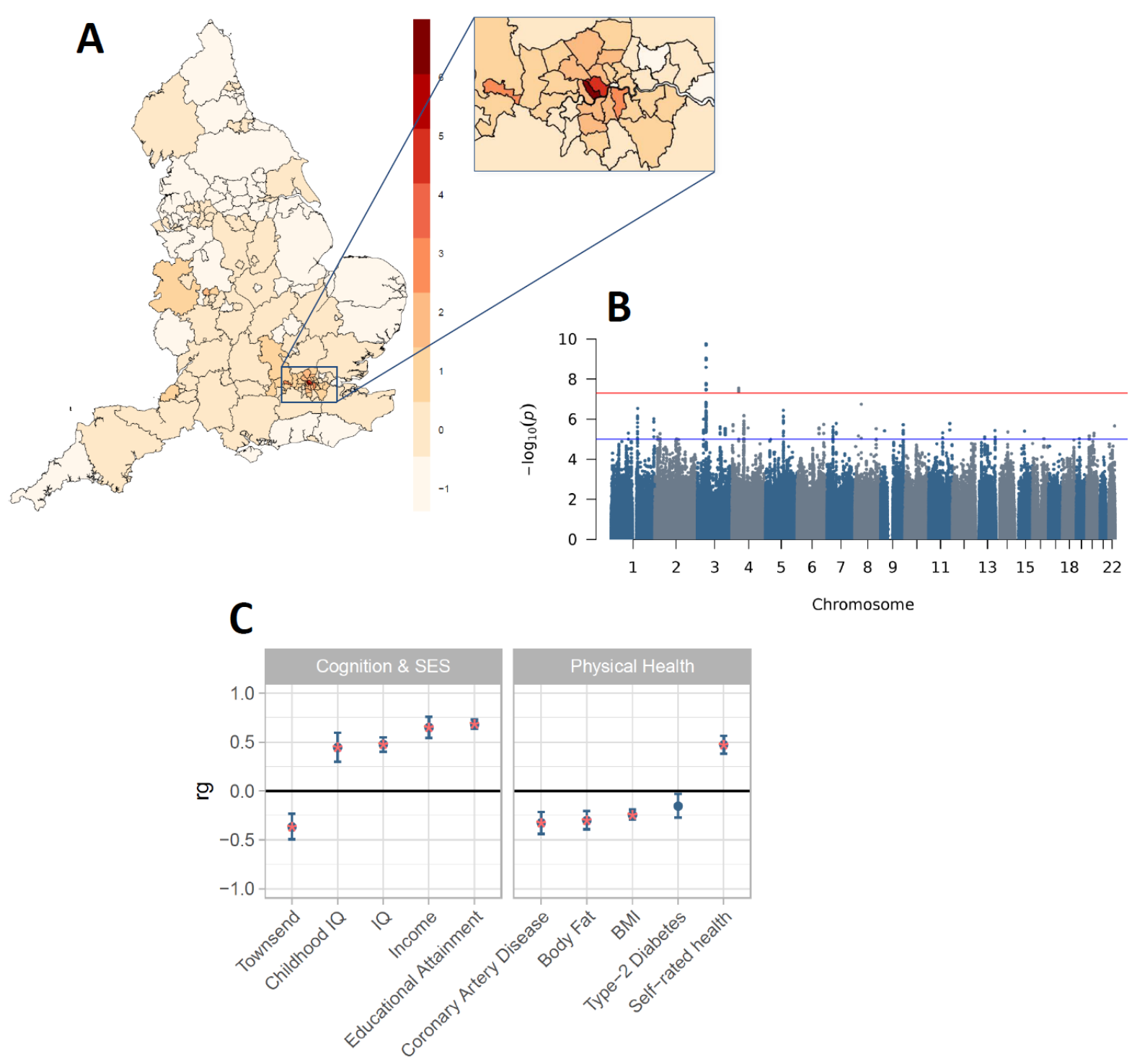

Figure 2: Case-rates on March $13^{\text {th }}$, the day with the highest SNP-based heritability. A: Geographic distribution of the reported Covid-19 case-rates on March 13 ${ }^{\text {th }}$, the day with the highest SNP-based heritability estimate. Color bar indicates distribution frequency of case-rate, scaled such that it has a mean of 0 and SD of 1. B: Manhattan Plot of the RGWAS of caserates on March $13^{\text {th }}$. The suggestive significance threshold (blue line) is set at $1 \times 10^{-5}$, and the genome-wide significance threshold (red line) is set at $5 \times 10^{-8}$. C: Genetic correlations $\left(r_{g}\right)$ of the RGWAS on Covid-19 case-rate on March $13^{\text {th }}$ with 5 SESrelated and 5 physical health traits as computed with LDSC regression (red stars indicate significance after Bonferroni correction, i.e., $p<.005)$. 
medRxiv preprint doi: https://doi.org/10.1101/2020.04.24.20075333; this version posted April 28, 2020. The copyright holder for this preprint (which was not certified by peer review) is the author/funder, who has granted medRxiv a license to display the preprint in perpetuity. It is made available under a CC-BY-NC-ND 4.0 International license.

\section{DISCUSSION}

We showed previously that social stratification and selective migration driven by socio-economic status (SES) has likely led to growing regional differences in genome-wide complex trait variation, especially for genes associated with educational attainment. ${ }^{11}$ Results of the current analyses suggest a temporary positive genetic relationship between the reported number of Covid-19 cases in March 2020 and regional SES and health. The strength of this genetic signal increased after controlling for population density by dividing the total number of regional cases by the regional population size. The positive genetic relationship between number of cases and higher SES and health increases in the beginning of the outbreak and then decreases as the number of cases rapidly rises and the disease spreads across the country. These results could reflect that 1) higher SES regions are more likely to have international travellers, including tourists, 2) people in higher SES regions are more likely to have higher levels of social contacts, or that 3) higher SES regions were more likely to have better testing capacities in the beginning of the pandemic. These genetic signals are in the other direction than one would expect based on epidemiological data on risk factors for more severe Covid-19 symptoms, ${ }^{12,13}$ which could supress genetic signals of interest when looking for polygenic signals associated with increased Covid-19 susceptibility.

The results confirm that the large UK Biobank dataset can be leveraged to combine real-time demographic data with genetic data through RGWAS to study the relationship between any regional dynamic variable and social stratification on a national level with high temporal resolution. The RGWAS approach should not be considered as an alternative to the traditional individual-level GWAS, as regional differences are of another nature than individual differences. ${ }^{11}$ Rather, the presence of polygenic signals in RGWAS results should serve as an indicator to proceed cautiously when interpreting the results of individual-level GWASs. The same limitations that were described in the last implementation of the RGWAS approach remain ${ }^{11}$, including the ascertainment bias in the UK Biobank towards a more healthy and higher educated population and the unknown bias in the regional data (in this case, the bias in the regional data may be related to testing capacity and/or hospital access), and gene-environment correlations inflating genetic signals.

This study combines longitudinal regional-level data with individual-level genotype data and GWAS summary statistics from 10 traits related to SES and health to investigate the nature of the polygenic effects associated with reported regional differences in Covid-19 infections. As large individual-level GWASs of Covid-19 susceptibilty are on the way, ${ }^{8}$ it is important to be aware that polygenic signals of Covid-19 susceptibility can contain genome-wide significant signals that reflect social differences in disease prevalence and/or testing capacity, and that these signals can vary over time. 
medRxiv preprint doi: https://doi.org/10.1101/2020.04.24.20075333; this version posted April 28, 2020. The copyright holder for this preprint (which was not certified by peer review) is the author/funder, who has granted medRxiv a license to display the preprint in perpetuity.

It is made available under a CC-BY-NC-ND 4.0 International license.

\section{MATERIALS AND MetHOdS}

\section{Participants}

The participants of this study come from UK Biobank (UKB), ${ }^{19,20}$ which has received ethical approval from the National Health Service North West Centre for Research Ethics Committee (reference: 11/NW/0382). A total of 502,536 participants (273,402 females and 229,134 males) aged between 37 and 73 years old were recruited in the UK between 2006 and 2010. The participants were recruited across 22 assessment centers throughout Great Britain in order to cover a variety of different settings providing socioeconomic and ethnic heterogeneity and urban-rural mix. They underwent a wide range of cognitive, health, and lifestyle assessments, provided blood, urine, and saliva samples, and will have their health followed longitudinally.

\section{Genotypes and Quality Control (QC)}

A total of 488,377 UKB participants had their genome-wide single nucleotide polymorphisms (SNPs) genotyped on either the UK BiLEVE array $(N=49,950)$ or the UK Biobank Axiom Array $(N=438,423)$. The genotypes were imputed using the Haplotype Reference Consortium (HRC) panel as a reference set (pre-imputation QC and imputation are described in more detail in Bycroft et al, 2018). ${ }^{20} \mathrm{We}$ extracted SNPs from HapMap3 CEU (1,345,801 SNPs) were filtered out of the imputed dataset. We then did a pre-PCA QC on unrelated individuals, filtering out SNPs with MAF $<.01$ and missingness > .05 , leaving 1,252,123 SNPs. After filtering out individuals with non-European ancestry, we repeated the SNP QC on unrelated Europeans ( $N=312,927)$, filtering out SNPs with MAF $<.01$, missingness $>.05$ and HWE $\mathrm{p}<10^{-10}$, leaving 1,246,531 SNPs. The HWE $\mathrm{p}$-value threshold of $10^{-10}$ was based on: http://www.nealelab.is/blog/2019/9/17/genotyped-snps-in-uk-biobank-failing-hardy-weinberg-

equilibrium-test. We then created a dataset of 1,246,531 QC-ed SNPs for 456,064 UKB subjects of European ancestry.

\section{Ancestry \& Principal Component Analysis}

To capture British ancestry, we first excluded individuals with non-European ancestry. Ancestry was determined using Principal Component Analysis (PCA) in GCTA. The UKB dataset was projected onto the first two principal components (PCS) from the 2,504 participants of the 1000 Genomes Project, using HM3 SNPs with minor allele frequency (MAF) > 0.01 in both datasets. Next, participants from UKB were assigned to one of five super-populations from the 1000 Genomes project: European, African, East-Asian, South-Asian, or Admixed. Assignments for European, African, East-Asian, and South-Asian ancestries were based on > 0.9 posterior-probability of belonging to the 1000 Genomes reference cluster, with the remaining participants classified as Admixed. Posterior-probabilities were calculated under a bivariate Gaussian distribution where this approach generalizes the k-means method to take account of the shape of the reference cluster. We used a uniform prior and calculated the vectors of means and $2 \times 2$ variance-covariance matrices for each super-population. A total of 456,064 subjects were identified to have a European ancestry. A PCA was then conducted on the individuals of European ancestry $(\mathrm{N}=456,064)$ in order to capture ancestry differences within the British population (see Figure 3 ). In order to capture ancestry differences in homogenous populations, genotypes should be pruned for LD and long-range LD regions removed. ${ }^{21}$ The LD pruned $\left(r^{2}<.2\right)$ UKB dataset without long-range LD regions consisted of 131,426 genotyped SNPS. The PCA to construct 
medRxiv preprint doi: https://doi.org/10.1101/2020.04.24.20075333; this version posted April 28, 2020. The copyright holder for this preprint (which was not certified by peer review) is the author/funder, who has granted medRxiv a license to display the preprint in perpetuity.

It is made available under a CC-BY-NC-ND 4.0 International license .

British ancestry-informative PCs was conducted on this SNP set for unrelated individuals using flashPCA V2. ${ }^{22}$ PC SNP loadings were used to project the complete set of European individuals onto the PCs.
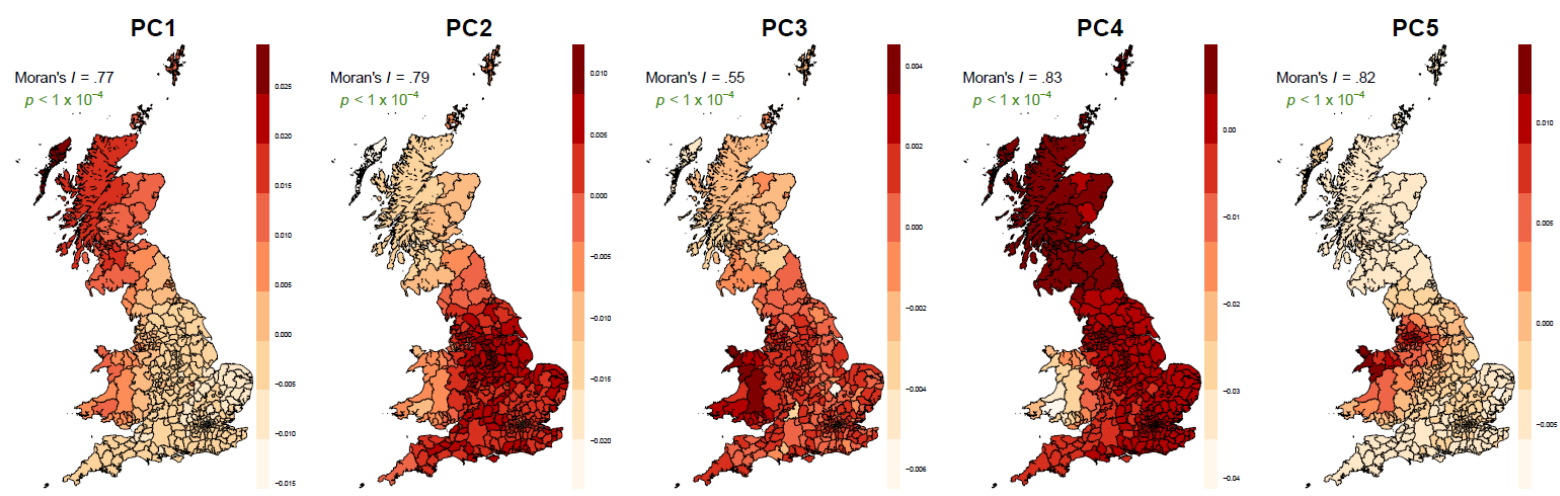

Figure 3: The geographic distributions (birthplace) of the first five PCs, Moran's I and empirical $p$-values for Moran's I. Pvalues denoted in green are significant after Bonferroni correction $(N=312,927$ unrelated individuals of European descent). ${ }^{11}$

\section{Genetic Relatedness Matrix}

The genetic relatedness matrices (GRMs) contain genetic relationships between all individuals based on a slightly LD pruned HapMap 3 SNP set (LD-pruning parameters used in PLINK: window size $=1000$ variant count, step size $=100, \mathrm{r} 2=0.9$ and MAF $>0.01$, resulting in 575,293 SNPs). The GRMs were computed using GCTA. ${ }^{23}$ We created a sparse GRM, containing only the relationships of related individuals (cut-off $=.05$, resulting in 179,609 relationships).

\section{Regional Genome-Wide Association Study (RGWAS)}

For the RGWASs, we ran linear mixed model (LMM) GWASs using fastGWA ${ }^{15}$ on participants with European ancestry, which controls for cryptic relatedness and population stratification by including a genetic relatedness matrix (GRM) in the model. ${ }^{24}$ The phenotypes were defined as the number or rate of reported Covid-19 cases in the local authority of the subject's current address. Sex and age were included as covariates, as were the first 100 PCs as an additional control for population stratification. As observed before with the RGWAS approach, ${ }^{11}$ the results revealed a considerable inflation of test statistics that was not due to polygenic effects, which was captured by LD score intercepts ${ }^{25}$. We controlled for this inflation with an LD score intercept-based genomic control, 25 i.e., we adjusted the standard errors (SE) of the estimated effect sizes as follows: $S E_{G C}=\sqrt{L D S C \text { intercept } * S E^{2}}$. For more details on the methods, rationale, and interpretation of the RGWAS approach, see Abdellaoui et al (2019) $)^{11}$.

\section{SNP-based heritability and genetic correlations}

SNP-based heritabilities and genetic correlations were computed using LD-score regression ${ }^{26}{ }^{26}$ The genetic correlation between traits is based on the estimated slope from the regression of the product of z-scores from two GWASs on the LD score and represents the genetic covariation between two traits based on all polygenic effects captured by the included SNPs. The genome-wide LD information used 
medRxiv preprint doi: https://doi.org/10.1101/2020.04.24.20075333; this version posted April 28, 2020. The copyright holder for this preprint (which was not certified by peer review) is the author/funder, who has granted medRxiv a license to display the preprint in perpetuity. It is made available under a CC-BY-NC-ND 4.0 International license.

by these methods were based on European populations from the HapMap 3 reference panel. ${ }^{25,26}$ All LD score regression analyses included the 1,290,028 million genome-wide HapMap SNPs used in the original LD score regression studies. ${ }^{25,26}$ The GWAS summary statistics for the traits for which we ran the genetic correlations (Figure 2C) are from: educational attainment, ${ }^{16}$ excluding all British cohorts $\left(\mathrm{N}=245,612\right.$, SNP-based $\left.h_{2}=.10\right)$, the Townsend ${ }^{27}\left(\mathrm{~N}=112,151\right.$, SNP-based $\left.h_{2}=.04\right)$, Childhood $I^{28}$ $\left(\mathrm{N}=12,441\right.$, SNP-based $\left.h_{2}=.28\right)$, Adult $\mathrm{IQ}^{29}\left(\mathrm{~N}=78,308\right.$, SNP-based $\left.h_{2}=.19\right)$, Income ${ }^{27}(\mathrm{~N}=112,151, \mathrm{SNP}$ based $\left.h_{2}=.06\right)$, Coronary Artery Disease ${ }^{30}\left(\mathrm{~N}=86,995\right.$, SNP-based $\left.h_{2}=.28\right)$, Body Fat ${ }^{31}(\mathrm{~N}=100,716$, SNPbased $\left.h_{2}=.10\right), \mathrm{BMI}^{32}\left(\mathrm{~N}=322,154\right.$, SNP-based $\left.h_{2}=.13\right)$, Type-2 Diabetes ${ }^{33}\left(\mathrm{~N}=69,033\right.$, SNP-based $\left.h_{2}=.18\right)$, Self-rated health ${ }^{34}\left(\mathrm{~N}=111,749\right.$, SNP-based $\left.h_{2}=.10\right)$.

\section{ACKNOWLEDGEMENTS}

This study has been conducted using UK Biobank resource under Application Number 40310. UK Biobank was established by the Wellcome Trust medical charity, Medical Research Council, Department of Health, Scottish Government and the Northwest Regional Development Agency. It has also had funding from the Welsh Assembly Government, British Heart Foundation and Diabetes UK. A.A. is supported by the Foundation Volksbond Rotterdam and by ZonMw grant 849200011 from The Netherlands Organisation for Health Research and Development. 
medRxiv preprint doi: https://doi.org/10.1101/2020.04.24.20075333; this version posted April 28, 2020. The copyright holder for this preprint (which was not certified by peer review) is the author/funder, who has granted medRxiv a license to display the preprint in perpetuity.

\section{REFERENCES}

Wu, F. et al. A new coronavirus associated with human respiratory disease in China. Nature 579, 265-269 (2020).

2 Zhou, P. et al. A pneumonia outbreak associated with a new coronavirus of probable bat origin. Nature 579, 270-273 (2020).

3 Care, D. o. H. a. S. COVID-19: government announces moving out of contain phase and into delay <https://www.gov.uk/government/news/covid-19-government-announces-movingout-of-contain-phase-and-into-delay> (2020).

4 Visscher, P. M. et al. 10 years of GWAS discovery: biology, function, and translation. The American Journal of Human Genetics 101, 5-22 (2017).

5 Chapman, S. J. \& Hill, A. V. Human genetic susceptibility to infectious disease. Nature Reviews Genetics 13, 175-188 (2012).

6 Nelson, M. R. et al. The support of human genetic evidence for approved drug indications. Nature genetics 47, 856 (2015).

$7 \quad$ King, E. A., Davis, J. W. \& Degner, J. F. Are drug targets with genetic support twice as likely to be approved? Revised estimates of the impact of genetic support for drug mechanisms on the probability of drug approval. PLoS Genetics 15 (2019). Kaiser, J. How sick will the coronavirus make you? The answer may be in your genes. Science (New York, N.Y.) March 27th (News) (2020).

9 Bycroft, C. et al. The UK Biobank resource with deep phenotyping and genomic data. Nature 562, 203-209 (2018).

10 England, P. H. COVID-19: track coronavirus cases, <https://www.gov.uk/government/publications/covid-19-track-coronavirus-cases> (2020). Abdellaoui, A. et al. Genetic correlates of social stratification in Great Britain. Nature human behaviour 3, 1332-1342 (2019).

12 Onder, G., Rezza, G. \& Brusaferro, S. Case-fatality rate and characteristics of patients dying in relation to COVID-19 in Italy. Jama (2020).

13 Wu, Z. \& McGoogan, J. M. Characteristics of and important lessons from the coronavirus disease 2019 (COVID-19) outbreak in China: summary of a report of 72314 cases from the Chinese Center for Disease Control and Prevention. Jama (2020).

14 Statistics, O. o. N. Official Labour Market Statistics. (2020).

15 Jiang, L. et al. A resource-efficient tool for mixed model association analysis of large-scale data. Report No. 1546-1718, (Nature Publishing Group, 2019).

16 Lee, J. J. et al. Gene discovery and polygenic prediction from a 1.1-million-person GWAS of educational attainment. Nature genetics 50, 1112 (2018).

17 Bulik-Sullivan, B. K., Finucane, H. K., Anttila, V., Gusev, A. \& Day, F. R. An atlas of genetic correlations across human diseases and traits. Nature genetics 47, 1236-1241, doi:10.1038/ng.3406 (2015).

18 Bulik-Sullivan, B. K., Loh, P. R., Finucane, H. K., Ripke, S. \& Yang, J. LD Score regression distinguishes confounding from polygenicity in genome-wide association studies. Nature genetics 47, 291-295, doi:10.1038/ng.3406 (2015).

Sudlow, C. et al. UK biobank: an open access resource for identifying the causes of a wide range of complex diseases of middle and old age. PLoS medicine 12, e1001779 (2015). Bycroft, C. et al. The UK Biobank resource with deep phenotyping and genomic data. Nature 562, 203 (2018).

21 Abdellaoui, A. et al. Population structure, migration, and diversifying selection in the Netherlands. European journal of human genetics 21, 1277-1285 (2013).

22 Abraham, G., Qiu, Y. \& Inouye, M. FlashPCA2: principal component analysis of Biobank-scale genotype datasets. Bioinformatics (2017).

23 Yang, J., Lee, S. H., Goddard, M. E. \& Visscher, P. M. GCTA: a tool for genome-wide complex trait analysis. The American Journal of Human Genetics 88, 76-82 (2011). 
medRxiv preprint doi: https://doi.org/10.1101/2020.04.24.20075333; this version posted April 28, 2020. The copyright holder for this preprint (which was not certified by peer review) is the author/funder, who has granted medRxiv a license to display the preprint in perpetuity. It is made available under a CC-BY-NC-ND 4.0 International license .

24 Yang, J., Zaitlen, N. A., Goddard, M. E., Visscher, P. M. \& Price, A. L. Advantages and pitfalls in the application of mixed-model association methods. Nature genetics 46, 100-106 (2014).

25 Bulik-Sullivan, B. K. et al. LD Score regression distinguishes confounding from polygenicity in genome-wide association studies. Nature genetics 47, 291 (2015).

26 Finucane, H. K. et al. Partitioning heritability by functional annotation using genome-wide association summary statistics. Nature genetics 47, 1228-1235 (2015).

27 Hill, W. D. et al. Molecular genetic contributions to social deprivation and household income in UK Biobank. Current Biology 26, 3083-3089 (2016).

28 Benyamin, B. et al. Childhood intelligence is heritable, highly polygenic and associated with FNBP1L. Molecular psychiatry 19, 253 (2014).

29 Sniekers, S. et al. Genome-wide association meta-analysis of 78,308 individuals identifies new loci and genes influencing human intelligence. Nature Genetics (2017).

30 Nikpay, M. et al. A comprehensive 1000 Genomes-based genome-wide association metaanalysis of coronary artery disease. Nature genetics 47, 1121 (2015).

31 Lu, Y. et al. New loci for body fat percentage reveal link between adiposity and cardiometabolic disease risk. Nature communications 7, 10495 (2016).

32 Locke, A. E. et al. Genetic studies of body mass index yield new insights for obesity biology. Nature 518, 197-206 (2015).

33 Morris, A. P. et al. Large-scale association analysis provides insights into the genetic architecture and pathophysiology of type 2 diabetes. Nature genetics 44, 981 (2012).

34 Harris, S. E. et al. Molecular genetic contributions to self-rated health. International journal of epidemiology 46, 994-1009 (2016). 